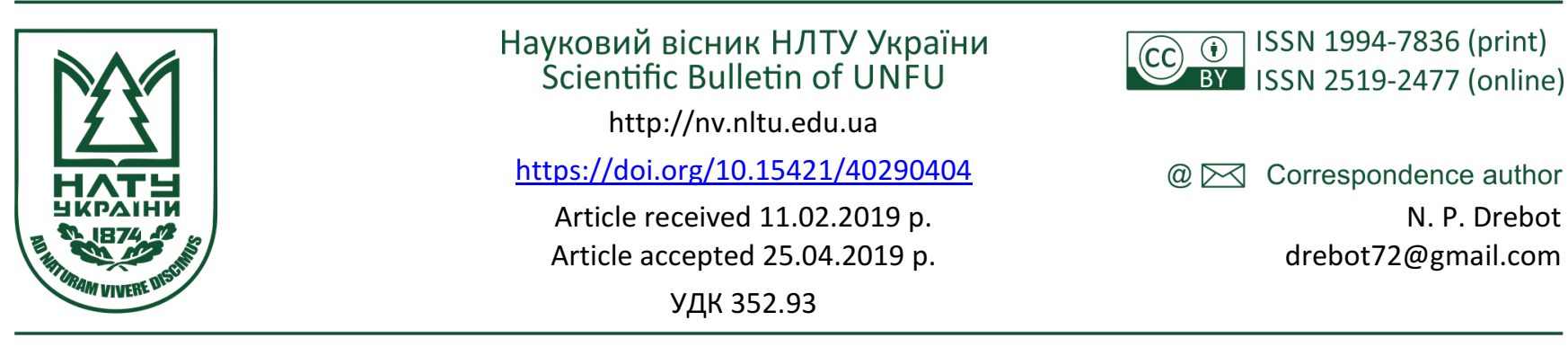

Н. П. Дребот, І. Б. Семеген

Львівський навчально-науковий інститут ДВНЗ "Університету банківської справи", м. Львів, Украйна

\title{
РЕФОРМА ДЕЦЕНТРАЛІЗАЦІЇ В УКРАЇНІ: ПОТОЧНИЙ СТАН ТА ПЕРСПЕКТИВИ РОЗВИТКУ
}

Досліджено особливості бюджетної децентралізації як складової частини реформи, що нині триває в Україні. Розкрито теоретичні основи бюджетної децентралізації, ії̈ сутнісні характеристики, функції, принципи та вплив на соціально-економічний розвиток регіонів. З'ясовано цільову спрямованість децентралізації задля створення економічно стабільного та збалансованого розвитку України. Виявлено ключові переваги та недоліки бюджетної децентралізації в Україні за останні роки. Проаналізовано динаміку створення об'єднаних територіальних громад. Виявлено вплив кількісних змін бази нарахування податків, зборів та обов'язкових платежів на динаміку зміни номінальних доходів місцевих бюджетів. Встановлено залежність місцевих бюджетів від Державного бюджету та недостатність обсягу власних і закріплених доходів для виконання самоврядних та делегованих повноважень. Виділено основні проблемні питання, котрі потребують вирішення для реалізації наймасштабнішої реформи в Україні.

Ключові слова: децентралізація; місцеве самоврядування; місцеві бюджети; податки та збори; офіційні трансферти.

Вступ. Розвиток України як незалежної держави 3 європейськими цінностями потребує підвищення якості державного управління у різних сферах економіки, формування ефективного місцевого самоврядування на засадах децентралізації влади та бюджетної системи.

Вирішення проблеми децентралізації $є$ частиною проблеми забезпечення ефективного функціонування багаторівневої бюджетної системи, головне призначення якої полягає у створенні умов для належного виконання органами місцевої влади своїх функціональних повноважень.

Бюджетна децентралізація є однією з фундаментальних умов незалежності та життєздатності органів місцевої влади, адже децентралізація процесів ухвалення рішень збільшує можливості участі місцевої влади у розвитку власної території, сприяє ефективному забезпеченню суспільними послугами шляхом ретельнішого узгодження видатків органів влади з найнеобхіднішими місцевими потребами.

У цьому контексті процес бюджетної децентралізації набуває особливого значення, оскільки реформи у фінансовій сфері покликані створити економічні стимули для органів місцевого самоврядування щодо розвитку своїх територій, розширення власної податкової бази та ефективного використання бюджетних коштів.

Матеріали та методика дослідження. Проблемами розбудови місцевого самоврядування як елементу бюджетної децентралізації в Україні досліджено у значній кількості робіт вітчизняних науковців. Так, у роботі М. Є. Чулаєвської розкрито особливості впливу Угоди про асоціацію на проведення внутрішніх реформ в Україні, зокрема реформи державного управління, державної служби; розглянуто положення Угоди про асоціацію, які наділяють ЄС важелями впливу на здійснення внутрішніх реформ в Україні; проаналізовано перебіг трансформацій державного управління та проведено порівняльний аналіз втілених змін (Chulaevskaya, 2016). У статті I. В. Форкун та П. В. Футорного визначено сутність та види децентралізації публічних фінансів, охарактеризовано зміст фінансово-бюджетної децентралізації та визначено децентралізацію доходів і видатків, процесуальну і організаційну самостійність як основні ії складові, запропоновано функціональну залежність, за якою можна оцінювати результативність фінансово-бюджетної децентралізації, розглянуто основні європейські моделі децентралізації публічної сфери та визначено за якою із них розвивається фінансово-бюджетна децентралізація в Україні (Forkun, \& Futornii, 2016). Перспективи використання європейського досвіду бюджетної децентралізації для України, особливості її запровадження, розглянуто в роботах Г. В. Возняк (Wozniak, 2016) та С. В. Онищенко (Onishchenko, 2016). Проблеми та перспективи формування сучасної системи публічних фінансів у Україні дослідили С. М. Клімова (Klimova, 2016), О. О. Молдован (Moldov, \& Postula, 2014). У наукових працях I. А. Нечаєвої проаналізовано формування та витрачання публічних фондів грошових коштів, виявлено напрями, особливості та проблеми формування та використання місцевих фінансів у Україні в умовах бюджетної децентралізації (Nechaeva, 2017).

\section{Інформація про авторів:}

Дребот Наталія Петрівна, канд. екон. наук, доцент, кафедра фінансів, банківської справи і страхування.

Email: drebot72@gmail.com; https://orcid.org/0000-0003-0742-0967

Семеген Ірина Богдановна, канд. екон. наук, ст. викладач, кафедра фінансів, банківської справи і страхування.

Email: dzedzyk-ira@ukr.net; https://orcid.org/0000-0003-0479-2132

Цитування за ДСтУ: Дребот Н. П., Семеген І. Б. Реформа децентралізації в Україні: поточний стан та перспективи розвитку. Науковий вісник НЛтУ України. 2019, т. 29, № 4. С. 24-27.

Citation APA: Drebot, N. P., \& Semehen, I. B. (2019). The reform of decentralization in Ukraine: the current state and development prospects. Scientific Bulletin of UNFU, 29(4), 24-27. https://doi.org/10.15421/40290404 
Однак, незважаючи на досить широке коло вирішуваних науковцями проблем, комплексний аналіз основних підсумків, результатів, проблем та наслідків впровадження бюджетної децентралізації в Україні є недостатнім.

Мета дослідження - проаналізувати результати, проблеми та наслідки впровадження реформи децентралізації в Україні.

Результати дослідження. Основною ознакою демократичної держави $є$ забезпечення зростання рівня благополуччя кожного окремого громадянина, а одною 3 головних передумов іiї розбудови - забезпечення правової, організаційної та фінансової автономії системи органів місцевого самоврядування (ОМС).

На сучасному етапі Україна неухильно спрямовує свої зусилля на реалізацію євроінтеграційного курсу, виконання міжнародно-правових зобов'язань, зокрема 3 питань розвитку місцевої і регіональної демократії. Саме тому подальша демократизація суспільства та одночасна децентралізація влади на засадах субсидіарності були і залишаються пріоритетами України.

Згідно із загальним визначенням, процес децентралізації- це реструктуризація або реорганізація влади, внаслідок якої виникає система спільної відповідальності установ на всіх рівнях управління (центральному, регіональному, місцевому) відповідно до принципу субсидіарності, що підвищує якість і ефективність системи управління та можливість участі народу в прийнятті економічних, соціальних, політичних рішень i забезпечує таким способом прозорість та оперативність втілення цих рішень у життя.

В Україні вектор на проведення децентралізаційних процесів закріплений у Концепції реформування місцевого самоврядування та територіальної організації влади від 1 квітня 2014 p. (Reform, 2014). Оскільки головним інструментом проведення соціально-економічної політики є бюджет, то саме бюджетна політика повинна сприяти сталому і ефективному економічному розвитку. Тому на сучасному етапі управління основою $є$ бюджетна децентралізація.

Бюджетна децентралізаџія - це процес передання повноважень (функцій, компетенцій і відповідальності) від центрального уряду до місцевих урядів (органів місцевого самоврядування). Така передача повноважень має супроводжуватися передачею відповідних фінансових ресурсів на виконання цих повноважень через запровадження місцевих податків або трансформацію чи закріплення частини загальнодержавних податків за місцевими бюджетами, що отримали нові повноваження. Бюджетною децентралізацією також є передача повноважень від вищих органів управління до нижчих, наприклад, від регіональних до муніципальних або місцевих. Зазвичай бюджетна децентралізація зумовлена прагненням центрального уряду поліпшити систему управління державою через реалізацію стратегічних та операційних цілей, кінцевою метою яких є створення безпечного середовища для життя людини (табл. 1).

Відповідно центральний уряд намагається "розвантажитися" від функцій, суть яких полягає в наданні послуг населенню і які потребують урахування особливостей потреб у цих послугах громадян залежно від місця їх проживання, етнічної належності, традицій та ін. Такі функції передаються регіонам, муніципалітетам або їхнім об'єднанням із закріпленням частини фінансових ресурсів держави та певних прав щодо встановлення і стягнення податків, здійснення запозичень. Держава бере на себе функцію фінансового вирівнювання або забезпечення приблизно однакового рівня надання одних і тих самих послуг на території всієї країни. Для цього вона надає трансферти, а також здійснює контроль чи моніторинг стану надання таких послуг місцевими органами влади. Тож ми узагальнили ключові переваги та недоліки бюджетної децентралізації в Україні за останні роки.

Табл. 1. Цільова спрямованість бюджетної децентралізації

\begin{tabular}{|c|c|c|}
\hline Стратегічна мета & Операційна мета & \begin{tabular}{|c} 
Завдання \\
\end{tabular} \\
\hline \begin{tabular}{l|} 
Створення \\
ефективної \\
системи влади
\end{tabular} & $\begin{array}{l}\text { Розмежування повноважень між ОМС та } \\
\text { державними органами влади; } \\
\text { Створення належних матеріальних, фі- } \\
\text { нансових та організаційних умов для ді- } \\
\text { яльності ОМС; } \\
\text { Забезпечення відкритості та прозорості } \\
\text { у вирішенні питань місцевого значення. }\end{array}$ & $\begin{array}{l}\text { Формування структури та повноважень ОМС; } \\
\text { Управління комунальною інфраструктурою; } \\
\text { Ефективне управління фінансовими ресурсами на місцевому рівні; } \\
\text { Децентралізація фінансових ресурсів - фіскальна децентралізація; } \\
\text { Забезпечення публічності та прозорості бюджетного процесу; } \\
\text { Створення системи взаємодії ОМС з громадськими організаціями. }\end{array}$ \\
\hline $\begin{array}{l}\text { Створення умов } \\
\text { для динамічного, } \\
\text { збалансованого } \\
\text { розвитку України } \\
\text { та її регіонів }\end{array}$ & $\begin{array}{l}\text { Підвищення рівня конкурентоспромож- } \\
\text { ності регіонів; } \\
\text { Територіальна соціально-економічна ін- } \\
\text { теграція і просторовий розвиток; } \\
\text { Ефективне державне управління у сфері } \\
\text { регіонального розвитку. }\end{array}$ & $\begin{array}{l}\text { Підвищення ефективності використання внутрішніх чинників роз- } \\
\text { витку регіонів; } \\
\text { Створення умов для поширення позитивних процесів розвитку } \\
\text { міст, розвиток сільської місцевості; } \\
\text { Розвиток міжрегіонального співробітництва; } \\
\text { Інституційне забезпечення регіонального розвитку; } \\
\text { Підвищення якості державного управління регіональним розвитком. }\end{array}$ \\
\hline $\begin{array}{l}\text { Забезпечення на- } \\
\text { дання якісних та } \\
\text { доступних послуг }\end{array}$ & $\begin{array}{l}\text { Державні стандарти надання послуг; } \\
\text { Спроможність надання послуг. }\end{array}$ & $\begin{array}{l}\text { Розроблення системи контролю з надання послуг; } \\
\text { Забезпечення професійності надання послуг; } \\
\text { Забезпечення належної інфраструктури для надання послуг. }\end{array}$ \\
\hline
\end{tabular}
Джерело: склав автор на основі опрацювання (Finance, 2019).

По-перше, це формування ОТГ. Основною перевагою бюджетної децентралізації $є$ іiї головна мета: раціоналізація формування та використання фінансових ресурсів на місцевому рівні шляхом стимулювання створення ОТГ, а також прирівнювання їх по статусу до міст обласного значення.

Активно процес створення нових адміністративних утворень відбувався вже у 2015 р. Так, влітку 2015 р. в Україні налічувалося 159 ОТГ. Отже, за два 3 полови- ною роки створено додатково 506 ОТГ. Їхня кількість збільшувалася щороку, починаючи з 2015 р., коли загалом було створено 159 ОТГ, у 2016 р. - 366, у 2017 р. 665. Тобто впродовж трьох років спостерігаємо щорічний приріст $+30 \%$. На грудень 2018 р. їх вже нараховується 865, загалом заплановано сформувати близько 1200 громад (Finance, 2019).

Лідерами серед областей з кількості утворених ОТГ є Дніпропетровська (56), Житомирська (45), Терно- 
пільська й Волинська - по 40 ОТГ. Найменше створено ОТГ у Закарпатській, Луганській, Київській та Донецькій областях - відповідно по 6, 8 і 9 ОТГ.

По-друге, це розмежування податків та зборів. Щоби стимулювати створення об'єднаних громад, до Закону про децентралізацію та Податкового кодексу включено норми про проведення бюджетної децентралізації, яка дала змогу ОТГ отримати додатковий ресурс для виконання переданих повноважень. Зокрема, ОТГ отримали повноваження та ресурси, які раніше надавалися тільки містам обласного значення, а саме - зарахування до місцевого бюджету 60 \% податку на доходи фізичних осіб. Окрім цього, територіальні громади отримують 100 \% з єдиного податку, податку на прибуток підприємств і фінансових установ комунальної власності та податку на майно (нерухомість, земля, транспорт). 3 іншого боку, ОТГ отримали право на державні трансферти для виконання повноважень: дотації, освітня та медична субвенції, субвенція на розвиток інфраструктури громад тощо.

Зростання номінальних доходів місцевих бюджетів пов'язане 3 кількісними змінами бази нарахування податків, зборів та обов'язкових платежів. Зокрема, у 2018 р. доходи місцевих бюджетів становили 502 млрд грн, що більш ніж удвічі перевищує показник 2014 р. та на 136 млрд грн більше від рівня надходжень 2017 р. (табл. 2).

За 9 місяців 2018 року сума надходжень до місцевих бюджетів становила 413,7 млрд грн. Однак динаміка реальних доходів порівняно з цінами 2007 р. (доходи в цінах, що порівнюються, визначали шляхом ділення номінальної суми надходжень на кумулятивний індекс цін виробників) не демонструє стійкого висхідного тренду і становить 69 млрд грн. Навпаки реальні доходи місцевих бюджетів у 2017 р. (99 млрд грн) та за 9 місяців 2018 р. (69 млрд грн) майже удвічі менші від рівня 2013 р. (114 млрд грн)

Табл. 2. Результати бюджетної децентралізації в Україні

\begin{tabular}{|l|c|c|c|c|c|c|c|c|}
\hline \multicolumn{1}{|c|}{ Показник } & \multicolumn{7}{|c|}{ Рі } \\
\cline { 2 - 10 } & 2011 & 2012 & 2013 & 2014 & 2015 & 2016 & 2017 & $9 \begin{array}{l}9 \text { міс. } \\
2018\end{array}$ \\
\hline $\begin{array}{l}\text { Доходи місцевих } \\
\text { бюджетів, млрд грн }\end{array}$ & 182 & 225 & 221 & 232 & 294 & 366 & 502 & 414 \\
\hline $\begin{array}{l}\text { Доходи місцевих } \\
\text { бюджетів у порівня- } \\
\text { них цінах 2007 р., } \\
\text { млрд грн }\end{array}$ & 95 & 118 & 144 & 91 & 92 & 84 & 99 & 69 \\
\hline $\begin{array}{l}\text { Офіційні трансфер- } \\
\text { ти, млрд грн }\end{array}$ & 95 & 124 & 116 & 131 & 174 & 195 & 272,6 & 226 \\
$\begin{array}{l}\text { Частка офіційних } \\
\text { трансфертів у стру- } \\
\text { ктурі доходів місце- } \\
\text { вих бюджетів, \% }\end{array}$ & 52,2 & 55,1 & 52,5 & 56,5 & 59,2 & 53,3 & 54,3 & 54,6 \\
\hline $\begin{array}{l}\text { Надходження місце- } \\
\text { вих податків, млрд } \\
\text { грн }\end{array}$ & 4,1 & 5,5 & 7,3 & 8,1 & 27,0 & 42,3 & 52,6 & 43,8 \\
\hline $\begin{array}{l}\text { Надходження місце- } \\
\text { вих податків у по- } \\
\text { рівняних цінах } \\
\text { 2007 р., млрд грн }\end{array}$ & 2,2 & 2,9 & 3,8 & 3,2 & 8,4 & 9,7 & 10,4 & 7,3 \\
\hline
\end{tabular}

Джерело: склав автор на основі опрацювання (Service, 2019; Finance, 2019).

Унаслідок податкової реформи відбулось зростання надходжень місцевих податків. У динаміці номінальної величини надходжень місцевих податків у 20152017 pp. та за 9 місяців 2018 р. проти періоду 2007-
2014 рр. дійсно відбулось значне збільшення цієї складової доходів місцевих бюджетів (табл. 2).

Якщо у 2013 р. сума надходжень місцевих податків становила 7,3 млрд грн, то у 2017 р. - 52,6 млрд грн, за 9 місяців 2018 р.- 43,8 млрд грн. Хоча в цінах, що порівнюються, зростання на декілька порядків не спостерігається. Наявне збільшення суми номінальних надходжень місцевих податків зумовлене переведенням 3 2015 р. плати за землю з категорії "збори за спеціальне використання природних ресурсів" у категорію "місцеві податки".

По-третє, це зміни в частині неподаткових надходжень та офіційних трансфертів. Щодо неподаткових надходжень, то їх зміни істотно не впливають на балансування бюджетів. Цікавішими є зміни в розділі офіційних трансфертів.

Більшість місцевих бюджетів є більш ніж на половину залежною від офіційних трансфертів. Частка офіційних трансфертів у доходах місцевих бюджетів, починаючи з 2011 р. і завершуючи 9 місяцями 2018 р. перевищує $50 \%$. Зокрема, якщо у 2007-2010 рр. питома вага офіційних трансфертів у структурі доходів місцевих бюджетів становила 42,1-49,1\%, то у 2017 р. $54,3 \%$, за 9 місяців 2018 р. - 54,6 \% (див. табл. 2).

Зростання частки державних трансфертів у доходах місцевих бюджетів свідчить про значну залежність місцевих бюджетів від Державного та недостатність обсягу власних і закріплених доходів для виконання самоврядних та делегованих повноважень. Тобто міжбюджетні трансферти залишаються гарантами фінансової спроможності бюджетів місцевих органів влади, які їх отримують.

На нашу думку, така тенденція $є$ наслідком недосконалого розподілу доходно-видаткових повноважень між рівнями управління, а також слабкої мобілізації доходної частини місцевих бюджетів через низький розвиток економічного простору держави.

По-четверте, громади отримали додаткові повноваження - здійснення зовнішніх запозичень, самостійне обрання установ $з$ обслуговування коштів місцевих бюджетів відносно розвитку та власних надходжень бюджетних установ. Також громади отримали повноваження у сфері архітектурно-будівельного контролю та вдосконалення містобудівного законодавства. Відтепер органи місцевого самоврядування можуть самостійно визначати містобудівну політику. Міністерство фінансів встановлює нормативний показник: сума відсотків, які місто сплачує за позиками, має бути не більшою за $10 \%$ від видатків загального фонду бюджету.

Висновки. Упродовж періоду проведення реформи децентралізації існують такі невирішені проблеми, які створюють ризики для успішної їі реалізації.

1. Створення об'єднаних територіальних громад переважно не має підтримки з боку широких верств населення, адже люди не розуміють сам процес децентралізації, а також стикаються зі спротивом з боку районних адміністрацій і місцевих рад. Вони перешкоджають утворенню ОТГ через страх втратити робочі місця та повноваження, бо процес їх створення супроводжується переформатуванням органів влади та змінами в управлінні на користь громад.

2. Швидке збільшення кількості ОТГ без пропорційного збільшення обсягу субвенції на розвиток інфраструктури знижує мотивацію громад до об'єднання та їхні можливості щодо соціально-економічного розвитку. 
3. На сьогодні не врегульовано питання розподілу повноважень між органами місцевого самоврядування та органами виконавчої влади загалом, а також функцій та повноважень між місцевими радами ОТГ та районними державними адміністраціями, районними радами. У рамках реформи необхідно чітко визначити повноваження, які залишаються за райдержадміністрацією та райрадою, переглянути чисельність та відповідно видатки на утримання їхніх апаратів.

4. В утворених об'єднаних територіальних громадах немає належно підготованих робочих кадрів та спостерігається низька кваліфікація службовців місцевого самоврядування для виконання нових функцій. Це призводить до неефективного використання фінансових ресурсів територіальних громад, неспроможності освоїти кошти державних субвенцій на розвиток.

5. Враховуючи високі ризики корупційних дій щодо використання бюджетних коштів, актуальним $€$ питання запровадження механізмів контролю за діяльністю органів місцевого самоврядування, як з боку державних органів, так і з боку громадськості. В умовах бюджетної децентралізації $є$ потреба здійснення належного контролю за роботою органів влади різних рівнів під час планування та виконання ними бюджетів, управління і використання фінансових ресурсів.

6. Для завершення процесу децентралізації на порядку денному залишаються десятки законопроектів, які стосуються регулювання земельних відносин та права громад розпоряджатися землями за межами населених пунктів. Також очікується прийняття законопроекту про муніципальну варту, проектів законів, які розмежують повноваження у сфері освіти, охорони здоров'я, культури, інфраструктури між ОТГ, іншими органами місцевого самоврядування та виконавчою владою.

Значною мірою дискредитує ідею бюджетної децентралізації волюнтаристське положення Закону № 2497 "Про внесення змін до Податкового кодексу та деяких законів щодо стимулювання утворення та діяльності сімейних фермерських господарств", яке запроваджує земельний податок на лісові землі. Постійні лісокористувачі вже сплачують рентну плату за спеціальне використання лісових ресурсів, яка включає і плату за користування землями лісового фонду. У разі запровадження такого податку постійні лісокористувачі будуть змушені підняти відпускні ціни на ділову та дров'яну деревину, що в першому випадку "підкосить" рівень конкурентоспроможності продукції вітчизняних деревообробників, а в другому - сприятиме нарощенню соціальної напруги у сільській місцевості у зв'язку із подорожчанням дров. Тому земельний податок на лісові землі завдасть місцевому самоврядуванню більшу суму збитків, аніж забезпечить приріст платежів у бюджети територіальних громад.

\section{Перелік використаних джерел}

Chulaevskaya, M. E. (2016). Reform of public administration in Ukraine according to the European model: from plans to disappointments. Vestnik NAPA at the President of Ukraine No. 1, 80-86. [In Ukrainian].

Finance. (2019). Official website of the Ministry of Finance of Ukraine. Retrieved from: http://www.minfin.gov.ua. [In Ukrainian].

Forkun, I. V., \& Futornii, P. V. (2016). Financial and budgetary decentralization - the European choice of Ukraine. Retrieved from: http://elartu.tntu.edu.ua/bitstream/lib/21471/1/Dubai_Vol 8, No 8 (2016).pdf. [In Ukrainian].

Klimova, S. M. (2016). Public finance management as a component of public administration reform in Ukraine. Retrieved from: http://www.law.stateandregions.zp.ua/archive/3_2016/17.pdf. [In Ukrainian].

Moldov, A. O., \& Postula, M. (2014). Modernization of the public finance system and the introduction of a new management model. Strategic Priorities, 2(31), 35-42. [In Ukrainian].

Nechaeva, I. A. (2017). Directions, peculiarities and problems of the formation and use of local finances in Ukraine under conditions of budget decentralization. Economy and the state, 7, 40-48. [In Ukrainian].

Onishchenko, S. V. (2016). Budget Decentralization: Peculiarities of Implementation, Problems and Perspectives. Finances, accounting, banks, 1(21), 145-153. [In Ukrainian].

Reform. (2014). Concepts of Reform of Local Self-Government and Territorial Organization of Power from April 1. Retrieved from: http://zakon.rada.gov.ua/. [In Ukrainian].

Service. (2019). Official site of the State Statistics Service of Ukraine. Retrieved from: http://www.ukrstat.gov.ua. [In Ukrainian].

Wozniak, G. V. (2016). Budget Decentralization: European Experience and Prospects for Ukraine. Retrieved from: http://ird.gov.ua/sep/sep20163(119)/sep20163(119)_056_Voznyak HV.pdf. [In Ukrainian].

Lviv Educational and Research Institute of Banking University, Lviv, Ukraine

\section{THE REFORM OF DECENTRALIZATION IN UKRAINE: THE CURRENT STATE} AND DEVELOPMENT PROSPECTS

Decentralization is a process aimed at creating an effective structure of local self-government bodies with signs of openness and flexibility, which will help to strengthen representative decision-making systems at the community level. By empowering local communities to manage their own affairs, as well as deepening cooperation between central and local authorities, an efficient system of local self-government will allow them to respond more adequately to the needs and priorities of people of a community, thereby ensuring that the government is able to regulate a wide range of economic and social issues, for instance, the problem of poverty reduction, job creation, gender equality, and environmental protection. Moreover, the introduction of a full-fledged local selfgovernment of the European model will enable the country to fully integrate into the European community. Therefore, the purpose of the article is to analyse the results, problems and consequences of the implementation of the decentralization reform in Ukraine. In the course of the research the essence of decentralization is defined; mechanisms that are used nowadays to increase the financial autonomy of local authorities are outlined. The influence of decentralization on the economic nature and socio-economic development of regions is grounded. The key advantages and disadvantages of budget decentralization in Ukraine in recent years have been revealed. The dynamics of creation of united territorial communities is analysed. The influence of quantitative changes in the basis of the calculation of taxes, fees and compulsory payments on the dynamics of changes in the nominal revenues of local budgets is revealed. The dependence of local budgets on the State Budget and insufficiency of the volume of own and fixed revenues for the implementation of self-governing and delegated powers were identified. The proposals aimed at increasing the efficiency of budgetary regulation in the process of implementing reforms, which will be considered when developing and using tools and methods for improving budgetary regulation, have been developed.

Keywords: decentralization; local self-government; local budgets; taxes and fees; official transfers. 